Jurnal Mahasiswa BK An-Nur : Berbeda, Bermakna, Mulia

Volume 7 Nomor 3 Tahun 2021

Tersedia Online: https://ojs.uniska-bjm.ac.id/index.php/AN-NUR

p-ISSN. 2460-9722 | e-ISSN. 2622-8297

\title{
DETERMINANT VIRAL LOAD TERSUPRESI TERHADAP PASIEN HIV DAN AIDS
}

\author{
Ersi Dewanti ${ }^{1}$, Handayani ${ }^{2}$ \\ ${ }^{1,2}$ Sekolah Pasca Sarjana Universitas Prof DR. Hamka, Fakultas Ilmu Kesehatan Masyarakat, \\ Jalan Warung Jati Barat, Jakarta Selatan, 12740, Indonesia, \\ E-mail: ersiimutz@yahoo.co.id/ Phone:089505537555
}

\begin{abstract}
ABSTRAK
Pemeriksaan tes viral load (VL) merupakan standar utama dan metode paling efektif untuk memantau Orang Dengan HIV/AIDS (ODHA) yang sedang menjalani therapi Antiretroviral (ARV). VL merupakan tes untuk menentukan virus HIV berada didalam setiap mililiter darah ODHA yang dinyatakan dalam satuan "Copies" Tes Viral Load dilakukan untuk mengetahui informasi kesehatan dan seberapa efektif terapi ARV yang dijalankan. Tujuan: Viral Load tersupresi Metode: menggunakan sistematik jumlah literatur review. Electronic database dari jurnal yang dipublikasikan melalui Google Scholar, Pubmed, Science direct, Research Gate. Hasil: Review lima jurnal menyatakan bahwa yang dapat berhubungan dengan keputusan ODHA untuk menjalankan tes VL antara lain adalah umur, jenis kelamin, lama hidup dengan HIV positif, lamanya minum ARV, jenis obat ARV yang diminum dan Status klinis ODHA terhadap Infeksi Oportunistik. Hasil penelitian menunjukkan determinant viral load tersupresi yang merupakan penguatan intervensi ODHA dalam menjalankan perawatan dan pengobatan ARV. Kesimpulan: Diharapkan hasil Viral load tersupresi dimana menunjukkan keberhasilan prognosis dan keberhasilan therapi ARV pada pasien HIV dan AIDS serta dapat memprediksi respon terapi.
\end{abstract}

Kata Kunci : HIV/AIDS, Therapi ARV, Viral load tersupresi.

\begin{abstract}
The viral load (VL) test is the main standard and the most effective method for monitoring people living with HIVIAIDS (PLWHA) who are undergoing antiretroviral (ARV) therapy. VL is a test to determine the presence of the HIV virus in every milliliter of PLWHA's blood expressed in "Copies" units. The Viral Load test is performed to find out health information and how effective ARV therapy is. Objective: Suppressed Viral Load Method: Using a systematic amount of literature review. Electronic database of journals published through Google Scholar, Pubmed, Science direct, Research Gate. Results: A review of five journals stated that those related to the decision of PLWHA to carry out the VL test included age, sex, length of life with HIV positive, duration of taking ARVs, types of ARV drugs taken and clinical status of PLWHA against opportunistic infections. The results showed that the determinant of suppressed viral load was a strengthening of the intervention of PLWHA in carrying out ARV care and treatment.Conclusion: It is hoped that the results of suppressed viral load will show the success of the prognosis and the success of ARV therapy in HIV and AIDS patients and can predict the response to therapy.
\end{abstract}

Keywords: HIV/AIDS, ARV therapy, suppressed viral load.

Dipublikasikan Oleh :

UPT Publikasi dan Pengelolaan Jurnal

Universitas Islam Kalimantan Muhammad Arsyad Al-Banjari Banjarmasin 


\section{Ersi Dewanti ${ }^{1}$, Handayani $^{2}$ \\ Jurnal Mahasiswa BK An-Nur : Berbeda, Bermakna, Mulia \\ Volume 7 Nomor 3 Tahun 2021 \\ Tersedia Online: https://ojs.uniska-bjm.ac.id/index.php/AN-NUR}

p-ISSN. 2460-9722 | e-ISSN. 2622-8297

\section{PENDAHULUAN}

Pemantauan orang yang memakai ARV penting untuk memastikan pengobatan yang berhasil untuk mengidentifikasi masalah kepatuhan dan menentukan apakah rejimen ARV harus diganti jika pengobatan gagal. Tes viral load telah menjadi standar utama untuk pengobatan Bersama dengan algoritma pemantauan pengobatan untuk mengidentifikasi kegagalan pengobatan(1)

Memberikan intervensi kepatuhan pengobatan dan mengidentifikasi kemungkinan resistensi obat yang mungkin memerlukan transisi individu ke rejimen ARV lini kedua. Sejak tahun 2016 terdapat peningkatan yang signifikans terhadap tes viral load dengan intervensi pengobatan dengan sekitar 20 juta tes viral load di negara-negara berpenghasilan rendah dan menengah pada tahun 2020. Terlepas dari peningkatan ini masih didapatkan beberapa masalah-masalah dan tantangan terhadap akses tes viral load maka itu perlu diperluas ke semua orang dengan HIV karena hasil tes tidak selalu digunakan secara konsisten untuk pengambil keputusan klinis, algoritme pemantauan pengobatan memerlukan revisi dengan rejimen obat yang optimal dan efektif. ${ }^{2}$

Bukti baru menunjukkan bahwa tekhnologi tes viral load di tempat perawatan dapat meningkatkan waktu penyelesaian tes, tingkat penekanan virus, dan mencegah penularan selain itu juga dengan rejimen ARV yang lebih baru dan lebih kuat diperkenalkan pada tahun 2019, proses pedoman ini mencakup tinjauan kritis terhadap algoritme pemantauan pengobatan sebelumnya untuk memastikan perawatan pasien yang optimal dalam konteks bukti dan alat baru yang tersedia sejak tahun $2016 .^{3}$

Berdasarkan data kasus HIV- AIDS di dunia yaitu United Nations Programme on HIV and AIDS Populasi terinfeksi HIV terbesar di dunia terjadi di Benua Afrika sebesar 25,7 juta orang, kemudian di Asia Tenggara 3,8 juta orang dan di Amerika sebesar 3,5 juta orang sedangkan yang terendah terjadi di Pasifik barat sebanyak 1,9 juta orang. Berdasarkan data tersebut didapat populasi kunci yang berisiko HIV secara global adalah pekerja seks yaitu sebesar $6 \%$, Pengguna Narkoba jarum suntik sebesar $12 \%$, Laki-laki suka laki-laki (laki-laki melakukan hubungan seks dengan sesama jenis) sebesar $17 \%$, wanita transgender $(1 \%)$, pelanggan pekerja seks dan partner seks dari populasi berisiko sebesar $18 \%$ dan populasi lain yang bukan populasi kunci (masyarakat umum) sebesar $46 \%$. Tingginya populasi orang terinfeksi HIV di Asia tenggara sehingga mengharuskan Indonesia untuk lebih waspada terhadap penyebaran dan penularan pada virus HIV ini. $^{4}$

Saat ini Indonesia berkomitmen untuk mempercepat peningkatan akses pengobatan di rumah sakit dengan layanan yang berkualitas melalui strategi STOP (Suluh, Temukan, Obati, Pertahankan) dan fast track 95-95-95. Secara umum, penyediaan layanan pengobatan masih menghadapi sejumlah tantangan, terutama yang berkaitan dengan sumber daya manusia untuk kesehatan. Indonesia berupaya untuk memaksimalkan pelayanan kesehatan khususnya rumah sakit dalam memberikan Perawatan, Dukungan dan Pengobatan (PDP) melalui pelatihan, termasuk didalamnya pengelolaan manajemen terpadu perawatan HIV dengan pendekatan terkini. ${ }^{5}$

Data Kaskade Laporan Perkembangan Kasus HIV di Indonesia ODHA ditemukan, diobati, dan hasil Viral Load (VL) tersupresi sampai dengan Desember 2020 yaitu ODHA pernah mulai pengobatan ART sebanyak 262.693 orang. ODHA pernah mulai pengobatan ART dan masih hidup sebanyak 215.039 orang. dengan ODHA yang meninggal setelah pernah mulai ART sebanyak 47.654 orang. Jumlah ODHA putus obat atau lost to follow up (LFU) sebanyak 65.779 orang. Jumlah ODHA menghentikan pengobatan ART sebanyak 6.354 orang. Jumlah ODHA yang sedang mendapatkan pengobatan sebanyak 142.906 orang. Jumlah ODHA yang sedang mendapatkan pengobatan yang dites VL minimum setelah 6 bulan pengobatan ARV sebanyak 37.068 orang, dengan hasil VL tersupresi sebanyak 33.027 orang. $^{6}$

Jumlah ODHA yang sedang mendapatkan pengobatan dan di tes VL minimum setelah 6 bulan pengobatan ARV sebanyak 37.068 dengan hasil VL tersupresi sebanyak 33.027 orang. Jumlah ODHA yang ditemukan (419.551) dan dilaporkan mencapai $77 \%$ dari jumlah etimasi ODHA hidup (543.100). ODHA yang rutin menerima pengobatan ARV sebanyak 26\% (142.906) dari estimasi ODHA (543.100) dengan Los to follow up /LFU setelah memulai pengobatan ARV (65.779) sebesar 26\% dari ODHA yang pernah memulai pengobatan ARV (262.693). ${ }^{6}$

Pemeriksaan tes viral load (VL) merupakan standar utama dan metode paling efektif untuk memantau Orang Dengan HIV/AIDS (ODHA) yang sedang menjalani therapi Antiretroviral (ARV). VL merupakan tes untuk menentukan jumlah virus HIV berada didalam setiap mililiter darah ODHA yang dinyatakan dalam satuan "Copies" Tes Viral Load

Dipublikasikan Oleh :

UPT Publikasi dan Pengelolaan Jurnal

Universitas Islam Kalimantan Muhammad Arsyad Al-Banjari Banjarmasin 
Ersi Dewanti ${ }^{1}$, Handayani $^{2}$

Jurnal Mahasiswa BK An-Nur : Berbeda, Bermakna, Mulia

Volume 7 Nomor 3 Tahun 2021

Tersedia Online: https://ojs.uniska-bjm.ac.id/index.php/AN-NUR

p-ISSN. 2460-9722 | e-ISSN. 2622-8297

dilakukan untuk mengetahui informasi kesehatan dan seberapa efektif terapi ARV yang dijalankan. Hasil tes viral load harus menunjukkan hasil yang optimal yaitu tidak terdeteksi sehingga Status klinis membaik, antibodi meningkat sehingga risiko Penularan menurun. ${ }^{7}$

Tujuan dari sistematik review ini adalah untuk mengetahui Viral Load tersupresi pada pasoen HIV dan AIDS. Kriteria yang terkait umur, jenis kelamin, lama hidup dengan HIV positif, lamanya atau kepatuhan minum ARV, jenis obat ARV yang diminum dan status klinis/kesehatan terhadap risiko Infeksi Oportunistik.

\section{METODE}

Penelitian ini menggunakan pendekatan Studi Literatur Review menggunakan metode Systematic Literature Review dengan Preferred Reporting Items for Systematic Reviews and Meta-analyses yang bertujuan untuk memproses identifikasi, menilai, memilih dan mensintesis secara sistematis sehingga terpilih referensi yang relevan untuk menjawab pertanyaan penelitian serta mencapai tujuan penelitian yaitu mengetahui factor-faktor yang berhubungan dengan viral load tersupresi pada pasien HIV-AIDS. Data yang digunakan dalam penelitian ini adalah data sekunder yang berasal dari artikel ilmiah nasional ataupun internasional dari tahun 2016-2021. Basis data yang digunakan yaitu Google Scholar, Pubmed, Science direct Research Gate, laporan perkembangan HIV-AIDS dan data sekunder yang bersumber pada Laporan SIHA Online Kemenkes RI. Strategi yang digunakan untuk pencarian Systematic Literatur Review menggunakan kata kunci HIV/AIDS, Therapi $A R V$, Viral load test. Kriteria inklusi yang digunakan dalam penelitian ini yaitu jurnal yang diambil publish dalam 5 tahun terakhir dengan minimal Sinta 4 dan menggunakan Quartile 3 dan Quartile 4. Penelitian juga menggunakan studi kuantitatif dan kasus penyakit.

Hasil

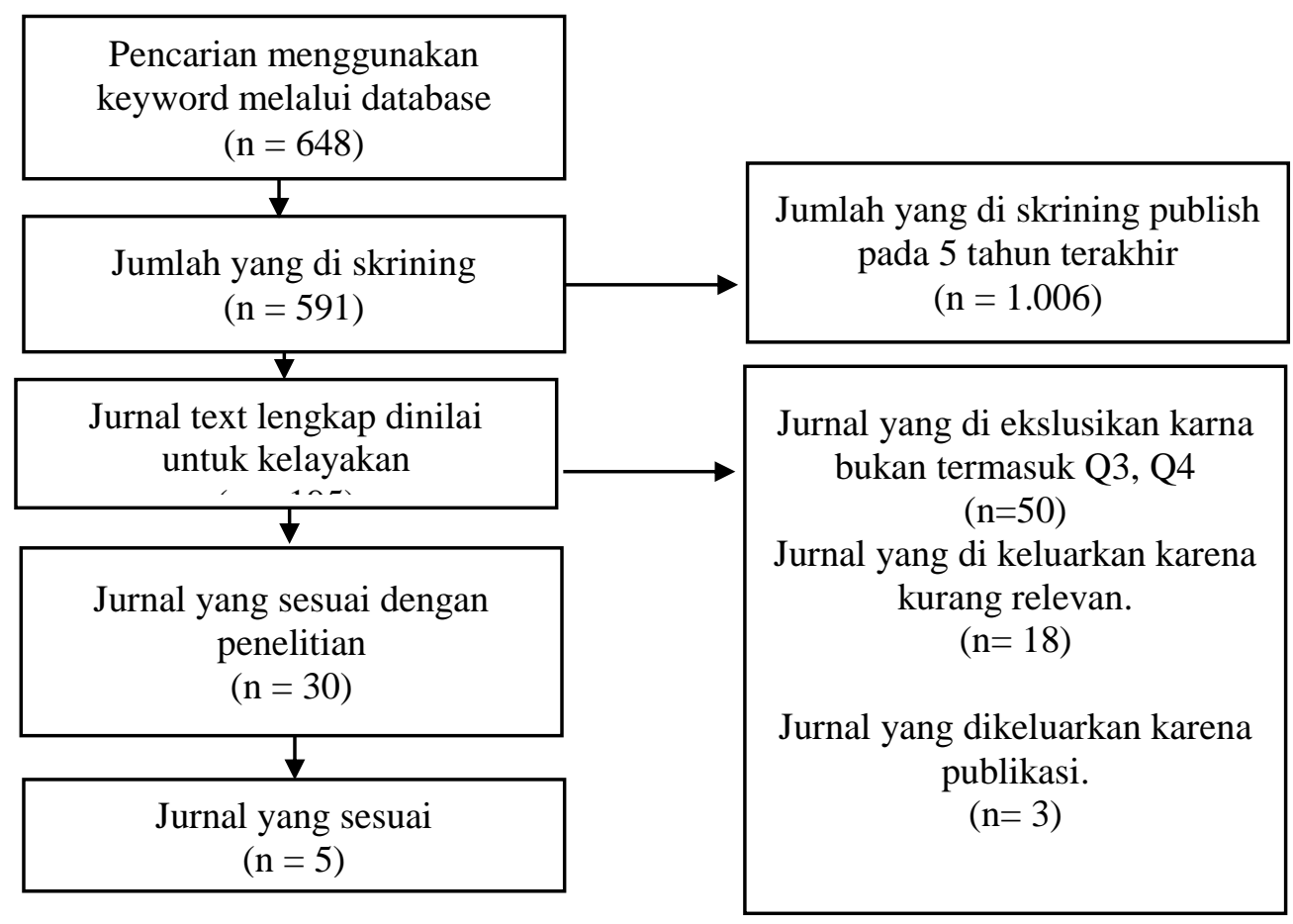

\section{HASIL DAN PEMBAHASAN}

Viral Load tes merupakan pemantauan pengobatan ARV yang paling utama untuk memastikan keberhasilan pengobatan dan dapat mengidentifikasi masalah kepatuhan pengobatan dan jika terjadi kegagalan pengobatan maka perlu dengan cepat melakukan intervensi dengan mengganti rejimen pengobatan lini kedua. Maka itu diperlukan regulasi regulasi untuk memperluas akses viral load tes untuk semua pasien dengan HIV dengan pengobatan ARV secara konsisten atau terjadwal dan memenuhi syarat untuk melakukan viral load tes. Viral load tes menjadi

Dipublikasikan Oleh :

UPT Publikasi dan Pengelolaan Jurnal

Universitas Islam Kalimantan Muhammad Arsyad Al-Banjari Banjarmasin 
rekomendasi sebagai pendekatan pemantauan pengobatan dan mengkonfirmasi kegagalan pengobatan dimana tes viral load menggunakan spesimen plasma karena lebih mudah untuk pemeriksaan. Viral load dapat dilakukan pada 6 bulan dan 12 bulan setelah melakukan pengobatan ARV kemudian setiap 12 bulan setelahnya.

Dari beberapa penelitian dapat ditinjau bahwa tes viral load dapat memungkinkan kemajuan substansial baik dalam pemahaman maupun dalam solusi teknis menuju urutan pemodelan. Eksperimen yang dilaporkan di sini mengevaluasi tekhnologi mengenai keefektifan dari pemeriksaan viral load tes. Secara global sekitar $53 \%$ peningkatan secara signifikan terhadap akses kepada pemberian terapi Antiretroviral Virus (ARV) orang yang positif AIDS. Agar pemberian pengobatan Antiretroviral Virus (ARV) dapat secara efektif didalam mempertahakan hidup penderita dan untuk mengetahui seberapa banyak muatan virus HIV yang terkandung pada penderita di dalam proses perawatan pemberian terapi Antiretroviral Virus (ARV), maka digunakan pemeriksaan Viral Load (VL) yang merupakan pendekatan pemantauan yang direkomendasikan untuk mengkonfirmasi kegagalan terapi Antiretroviral Virus (ARV) dimana VL sendiri dapat melihat jumlah Asam Ribonukleat dari HIV (RNA).

Berdasarkan hasil pencarian literatur didapatkan 648 artikel yang tersedia pada data base Google Scholar, Pubmed, Science direct Research Gate. Pencarian literatur dilakukan sesuai dengan kata kunci yang ditentukan. Skrining dilakukan dalam dua tahap yaitu skrining pertama menggunakan kata kunci umum yaitu viral load tes, dan skrining kedua menggunakan kata kunci lebih spesifik yaitu viral load tersupresi, skrining pertama di didapatkan 591 jurnal dan skrining kedua didapatkan 250 jurnal, kedua kata kunci tersebut digabungkan menjadi skrining tiga yaitu kata kunci status viral load supression dan didapatkan 195 jurnal. 50 artikel jurnal dikeluarkan karena dipublish >5tahun yang lalu, 18 artikel dikeluarkan karena tidak relevan, 3 artikel dikeluarkan karena duplikasi sehingga terpilihlah 5 jurnal yang digunakan sebagai tinjauan literatur dengan tabel 1 berikut;

Tabel 1. Tinjauan Literatur

\begin{tabular}{|c|c|c|c|c|c|c|c|}
\hline No & Nama Peneliti & $\begin{array}{c}\text { Tahun } \\
\text { Penelitian }\end{array}$ & $\begin{array}{l}\text { Nama } \\
\text { Jurnal }\end{array}$ & $\begin{array}{c}\text { Judul } \\
\text { penelitian }\end{array}$ & $\begin{array}{c}\text { Variabel } \\
\text { yang diteliti }\end{array}$ & Metode & Hasil \\
\hline 1 & $\begin{array}{l}\text { Madlen Nash,a,b } \\
\text { Sophie } \\
\text { Huddart,a,b } \\
\text { Sayema Badar,c } \\
\text { Shrikala } \\
\text { Baliga,d,e } \\
\text { Kavitha } \\
\text { Saravu,e,f } \\
\text { Madhukar Paia,b, }\end{array}$ & 2018 & $\begin{array}{l}\text { Journal of } \\
\text { Clinical } \\
\text { Microbiol } \\
\text { ogy } \\
\text { (8) }\end{array}$ & $\begin{array}{l}\text { Performance of } \\
\text { the Xpert HIV-1 } \\
\text { Viral } \quad \text { Load } \\
\text { Assay: } \\
\text { Systematic } \\
\text { Review and } \\
\text { Meta-analysis } \\
\text { Kinerja Tes } \\
\text { Viral Load } \\
\text { Xpert HIV-1: } \\
\text { Sistematis } \\
\text { Review dan } \\
\text { Meta-analisis }\end{array}$ & $\begin{array}{l}\text { Dependen: } \\
\text { Kinerja tes } \\
\text { viral load } \\
\text { Xpert HIV-1 } \\
\text { Independen: } \\
\text { demografi } \\
\text { pasien, } \\
\text { koefisien } \\
\text { korelasi, dan } \\
\text { hasil analisis } \\
\text { Bland-Altman } \\
\text { membandingk } \\
\text { an tes Xpert } \\
\text { HIV-1 VL dan } \\
\text { tes referensi } \\
\text { dan kualitas } \\
\text { studi }\end{array}$ & $\begin{array}{l}\text { tinjauan } \\
\text { sistematis } \\
\text { literatur } \\
\text { sesuai } \\
\text { dengan } \\
\text { pedoman } \\
\text { PRISMA } \\
\text { membandin } \\
\text { gkan uji } \\
\text { VL Xpert } \\
\text { HIV-1 } \\
\text { Cepheid } \\
\text { dengan uji } \\
\text { VL } \\
\text { berbasis } \\
\text { PCR } \\
\text { lainnya } \\
\text { ukuran } \\
\text { perbanding } \\
\text { an antara } \\
\text { Xpert VLs } \\
\text { dan VLs } \\
\text { standar } \\
\text { emas } \\
\text { (yaitu, } \\
\text { Pearson }\end{array}$ & $\begin{array}{l}\text { Secara } \\
\text { keseluruhan, } \\
\text { tinjauan } \\
\text { sistematis } \\
\text { kami } \\
\text { menunjukkan } \\
\text { Xpert HIV-1 } \\
\text { VL berkinerja } \\
\text { baik } \\
\text { dibandingkan } \\
\text { dengan uji VL } \\
\text { standar } \\
\text { referensi yang } \\
\text { ditetapkan } \\
\text { saat ini, baik } \\
\text { bila diukur } \\
\text { dengan } \\
\text { korelasi dan } \\
\text { dengan } \\
\text { analisis } \\
\text { Bland- } \\
\text { Altman. } \\
\text { Temuan ini } \\
\text { dapat } \\
\text { membantu } \\
\text { menginformas }\end{array}$ \\
\hline
\end{tabular}

Dipublikasikan Oleh :

UPT Publikasi dan Pengelolaan Jurnal

Universitas Islam Kalimantan Muhammad Arsyad Al-Banjari Banjarmasin 
Ersi Dewanti ${ }^{1}$, Handayani $^{2}$

Jurnal Mahasiswa BK An-Nur : Berbeda, Bermakna, Mulia

Volume 7 Nomor 3 Tahun 2021

Tersedia Online: https://ojs.uniska-bjm.ac.id/index.php/AN-NUR

p-ISSN. 2460-9722 | e-ISSN. 2622-8297

\begin{tabular}{|c|c|c|c|c|c|c|c|}
\hline & & & & & & $\begin{array}{l}\text { atau } \\
\text { Korelasi } \\
\text { Spearman, } \\
\text { perjanjian } \\
\text { Bland- } \\
\text { Altman, } \\
\text { dll.). }\end{array}$ & $\begin{array}{l}\text { ikan panduan } \\
\text { kebijakan }\end{array}$ \\
\hline 2 & $\begin{array}{l}\text { Sukarsi Rusti1), } \\
\text { Irmayeni Elinda2) }\end{array}$ & 2018 & $\begin{array}{l}\text { Jurnal } \\
\text { Human } \\
\text { Care } \\
\text { (9) }\end{array}$ & $\begin{array}{l}\text { Studi } \\
\text { Retrospektif } \\
\text { Ketahanan } \\
\text { Hidup Orang } \\
\text { Dengan Infeksi } \\
\text { HIV/AIDS } \\
\text { (ODHA) }\end{array}$ & $\begin{array}{l}\text { Variabel } \\
\text { Independen } \\
\text { lama } \\
\text { terinfeksi, } \\
\text { kepatuhan } \\
\text { meminum } \\
\text { obat ARV, } \\
\text { infeksi } \\
\text { oportunistik } \\
\text { dan variabel } \\
\text { dependen } \\
\text { adalah } \\
\text { ketahanan } \\
\text { hidup ODHA. }\end{array}$ & $\begin{array}{l}\text { desain } \\
\text { kohort } \\
\text { retrospektif } \\
\text { uji Chi- } \\
\text { Square }\end{array}$ & $\begin{array}{l}\text { terdapat } \\
\text { pengaruh } \\
\text { lama } \\
\text { terinfeksi, } \\
\text { kepatuhan } \\
\text { meminum } \\
\text { obat ARV dan } \\
\text { infeksi } \\
\text { oportunistik } \\
\text { terhadap } \\
\text { ketahanan } \\
\text { hidup ODHA. } \\
\text { Dari ketiga } \\
\text { variabel } \\
\text { didapatkan } \\
\text { yang paling } \\
\text { berhubungan } \\
\text { dan nilai } \\
\text { asosiasi } \\
\text { tertinggi } \\
\text { adalah lama } \\
\text { terinfeksi. }\end{array}$ \\
\hline 3 & $\begin{array}{l}\text { Robert LuoID1, } \\
\text { Jessica Markby2, } \\
\text { Jilian Sacks3 } \\
\text {,Lara VojnovID1 }\end{array}$ & 2019 & $\begin{array}{l}\text { PLOS } \\
\text { ONE | } \\
\text { https://doi. } \\
\frac{\text { org/10.137 }}{1 /} \\
\text { journal.po } \\
\text { ne.022539 } \\
3 \\
(10)\end{array}$ & $\begin{array}{l}\text { Systematic } \\
\text { review of the } \\
\text { accuracy of } \\
\text { plasma } \\
\text { preparation } \\
\text { tubes for HIV } \\
\text { viral load testing } \\
\text { Tinjauan } \\
\text { sistematik } \\
\text { review tentang } \\
\text { keakuratan } \\
\text { plasma tabung } \\
\text { persiapan untuk } \\
\text { tes viral load } \\
\text { HIV }\end{array}$ & $\begin{array}{l}\text { Variabel yang } \\
\text { digunakan } \\
\text { adalah akurasi } \\
\text { PPT untuk } \\
\text { evaluasi hasil } \\
\text { tes viral load } \\
\text { dengan } \\
\text { membandingk } \\
\text { an hasil yang } \\
\text { menggunakan } \\
\text { tabung EDTA } \\
\text { atau tabung } \\
\text { PPT sebagai } \\
\text { otoritas } \\
\text { regulasi }\end{array}$ & $\begin{array}{l}\text { Tinjauan } \\
\text { sistematik } \\
\text { disesuaikan } \\
\text { dengan } \\
\text { tekhnik } \\
\text { pelaporan } \\
\text { dengan } \\
\text { menggunak } \\
\text { an tijauan } \\
\text { meta } \\
\text { analisis }\end{array}$ & $\begin{array}{l}\text { Hasil viral } \\
\text { load setara } \\
\text { dengan } \\
\text { plasma dari } \\
\text { tabung EDTA } \\
\text { standar } \\
\text { dengan } \\
\text { penanganan } \\
\text { yang sesuai } \\
\text { standar } \\
\text { panduan } \\
\text { pengambilan } \\
\text { sampel. }\end{array}$ \\
\hline 4 & $\begin{array}{l}\text { Tracy Glass, } \\
\text { Landon Myer, } \\
\text { Maia Lesosky }\end{array}$ & 2020 & $\begin{array}{l}\text { MJ Global } \\
\text { Health } \\
\text { (11) }\end{array}$ & $\begin{array}{l}\text { The role of HIV } \\
\text { viral load in } \\
\text { mathematical } \\
\text { models of HIV } \\
\text { transmission and } \\
\text { treatment } \\
\text { Peran virus HIV }\end{array}$ & $\begin{array}{l}\text { Variabel yang } \\
\text { digunakan } \\
\text { adalah } \\
\text { intervensi } \\
\text { populasi yang } \\
\text { menjadi } \\
\text { model } \\
\text { matematika } \\
\text { sebagai }\end{array}$ & $\begin{array}{l}\text { Studi yang } \\
\text { melibatkan } \\
\text { hewan dan } \\
\text { analisis } \\
\text { yang tidak } \\
\text { menggunak } \\
\text { an simulasi } \\
\text { matematika } \\
\text { yang }\end{array}$ & $\begin{array}{l}\text { Perlakuan } \\
\text { yang } \\
\text { didapatkan } \\
\text { dari tes VL } \\
\text { terhadap } \\
\text { model terjadi } \\
\text { peningkatan } \\
\text { penekanan } \\
\text { dan }\end{array}$ \\
\hline
\end{tabular}

Dipublikasikan Oleh :

UPT Publikasi dan Pengelolaan Jurnal

Universitas Islam Kalimantan Muhammad Arsyad Al-Banjari Banjarmasin 
Ersi Dewanti ${ }^{1}$, Handayani $^{2}$

Jurnal Mahasiswa BK An-Nur : Berbeda, Bermakna, Mulia

Volume 7 Nomor 3 Tahun 2021

Tersedia Online: https://ojs.uniska-bjm.ac.id/index.php/AN-NUR

p-ISSN. 2460-9722 | e-ISSN. 2622-8297

\begin{tabular}{|c|c|c|c|c|c|c|c|}
\hline & & & & $\begin{array}{l}\text { beban dalam } \\
\text { model } \\
\text { matematika } \\
\text { transmisi dan } \\
\text { pengobatan HIV }\end{array}$ & $\begin{array}{l}\text { transmisi dan } \\
\text { pengobatan. }\end{array}$ & $\begin{array}{l}\text { termasuk } \\
\text { were } \\
\text { excluded. }\end{array}$ & $\begin{array}{l}\text { pemantauan } \\
\text { VL tes } \\
\text { sebagai alat } \\
\text { utama untuk } \\
\text { pengendali } \\
\text { HIV di tingkat } \\
\text { populasi dan } \\
\text { kebutuhan } \\
\text { yang jelas } \\
\text { untuk simulasi } \\
\text { epidemiologi } \\
\text { HIV } \\
\text { berdasarkan } \\
\text { tes VL. }\end{array}$ \\
\hline 5 & 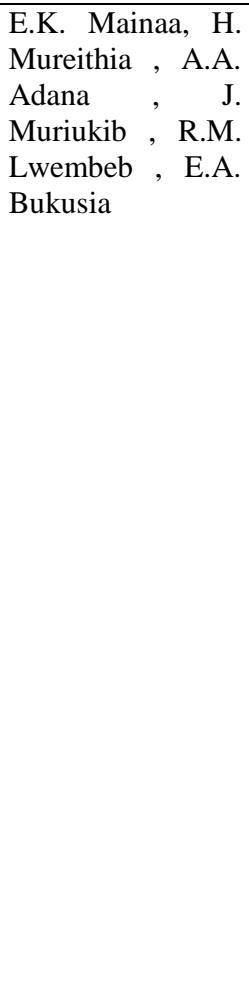 & 2020 & $\begin{array}{l}\text { journal } \\
\text { homepage: } \\
\text { www.else } \\
\text { vier.com/l } \\
\text { ocate/ijid } \\
\text { (12) }\end{array}$ & $\begin{array}{l}\text { Insidens dan } \\
\text { factor yang } \\
\text { terkait dengan } \\
\text { penekanan virus } \\
\text { atau rebound } \\
\text { diantara pasien } \\
\text { HIV yang } \\
\text { menggunakan } \\
\text { terapi ARV } \\
\text { Kombinasi dari } \\
\text { tiga kabupaten } \\
\text { di Kenya }\end{array}$ & $\begin{array}{l}\text { Orang yang } \\
\text { terinfeksi HIV } \\
\text { yang memakai } \\
\text { ARV dari } \\
\text { Kabupaten } \\
\text { Kilifi, Meru } \\
\text { dan Nakuru di } \\
\text { Kenya. } \\
\text { Dengan } \\
\text { peserta yang } \\
\text { dipilih riwayat } \\
\text { ARV, riwayat } \\
\text { pengobatan } \\
\text { dari setiap } \\
\text { penyakit } \\
\text { infeksi } \\
\text { oportunistik, } \\
\text { penekanan } \\
\text { virus dari } \\
\text { rendah atau } \\
\text { terdeteksi dan } \\
\text { tidak tak } \\
\text { terdeteksi. }\end{array}$ & $\begin{array}{l}\text { Menggunak } \\
\text { an } \\
\text { peneltian } \\
\text { retrospektif } \\
\text { yang } \\
\text { melibatkan } \\
600 \text { orang } \\
\text { terinfeksi } \\
\text { HIV yang } \\
\text { memakai } \\
\text { kombinasi } \\
\text { ARV }\end{array}$ & $\begin{array}{l}\text { Tingkat } \\
\text { penekanan } \\
\text { virus pada } \\
\text { pasien yang } \\
\text { menggunakan } \\
\text { kombinasi } \\
\text { ARV tidak } \\
\text { mencapai } \\
\text { target WHO } \\
\text { namun } \\
\text { penelitian ini } \\
\text { memberikan } \\
\text { bukti tingkat } \\
\text { VL yang tidak } \\
\text { terdeteksi } \\
\text { selama lebih } \\
\text { dari } 2 \text { tahun } \\
\text { dapat } \\
\text { mengendalika } \\
\text { n risiko } \\
\text { penularan } \\
\text { HIV tercapai } \\
\text { dan } \\
\text { merupakan } \\
\text { sebuah tanda } \\
\text { bahwa tujuan } \\
\text { PBB untuk } \\
\text { tahun 2030. }\end{array}$ \\
\hline
\end{tabular}

\section{REFERENSI}

WHO. HIV Prevention, Infant Diagnosis, Antiretroviral Initiation And Monitoring Guidelines. 2021.

World Health Organization. HIV Prevention, Testing, Treatment, Service Delivery And Monitoring [Internet].

2021.

Http://Apps.Who.Int/Bookorders.

Sub-Direktorat HIV/AIDS, Direktorat Jenderal Pencegahan Dan Pengendalian Penyakit Kementerian Kesehatan Republik Indonesia
Pedoman Penggunaan Rapidpro Dalam Program Fast Track HIV / AIDS V5.Pdf.

UNAIDS. "Data 2020." Programme On HIV/AIDS, 2020, Hal. 1-248.

Direktur Jenderal P2p, Kemenkes. Laporan Tw IV 2020.Pdf. 2020.

What's New In Treatment Monitoring: Viral Load And CD4 Testing, 2017

HK.01.07/MENKES/90/2019 tentang Pedoman Nasional Pelayanan Kedokteran Tata Laksana HIV." A $\gamma \alpha \eta$, vol. 8, no. 5, 2019, hal. 55.

Dipublikasikan Oleh :

UPT Publikasi dan Pengelolaan Jurnal

Universitas Islam Kalimantan Muhammad Arsyad Al-Banjari Banjarmasin 
Ersi Dewanti ${ }^{1}$, Handayani $^{2}$

Jurnal Mahasiswa BK An-Nur : Berbeda, Bermakna, Mulia

Volume 7 Nomor 3 Tahun 2021

Tersedia Online: https://ojs.uniska-bjm.ac.id/index.php/AN-NUR

p-ISSN. 2460-9722 | e-ISSN. 2622-8297

Madlen Nash,a,b Sophie Huddart,a,b Sayema Badar,c

Shrikala Baliga,d,e Kavitha Saravu,e,f

Madhukar Paia,b, Performance of the Xpert

HIV-1 Viral Load Assay: a Systematic Review

and Meta-analysisJournal of Clinical Microbiology,2018

Sukarsi Rusti1) , Irmayeni Elinda2) STUDI RETROSPEKTIF KETAHANAN HIDUP ORANG DENGAN INFEKSI HIV/AIDS (ODHA) Jurnal Human Care, 2018

Robert LuoID1 *, Jessica Markby2, Jilian Sacks2, Lara Vojnov1 Systematic review of the accuracy of plasma preparation tubes for HIV viral load testing PLOS ONE । https://doi.org/10.1371/journal.pone.0225393 November 21, 2019

Tracy Glass, Landon Myer, Maia Lesosky The role of HIV viral load in mathematical models of HIV transmission and treatment: a review Glass $\mathrm{T}$, et al. BMJ Global Health 2020;5:e001800. doi:10.1136/bmjgh-2019-001800

E.K. Mainaa, H. Mureithia , A.A. Adana , J. Muriukib , R.M. Lwembeb , E.A. BukusiaIncidences and factors associated with viral suppression or rebound among HIV patients on combination antiretroviral therapy from three counties in Kenya, International Journal of Infectious Diseases2020

Dipublikasikan Oleh :

UPT Publikasi dan Pengelolaan Jurnal

Universitas Islam Kalimantan Muhammad Arsyad Al-Banjari Banjarmasin 